\section{COD AND AMMONIA REMOVAL FROM LANDFILL LEACHATE USING MIXED GRANULAR ADSORBENT MEDIA}

\author{
Zawawi Dauda*, Mahmoud Hijab Abubakara, Ab Aziz Abdul Latiffa, \\ Halizah Awangb, Zulkifli Ahmada, Mohd Baharudin Ridzuana
}

aCentre of Advanced Research for Integrated Solid Waste Management. Faculty of Civil and Environment Engineering, Universiti Tun Hussein Onn Malaysia

bFaculty of Technical and Vocational Education, Universiti Tun Hussein Onn Malaysia
Article history

Received

24 July 2017

Received in revised form

30 January 2018

Accepted

15 February 2018

Published online

3 June 2018

*Corresponding author zawawi@uthm.edu.my

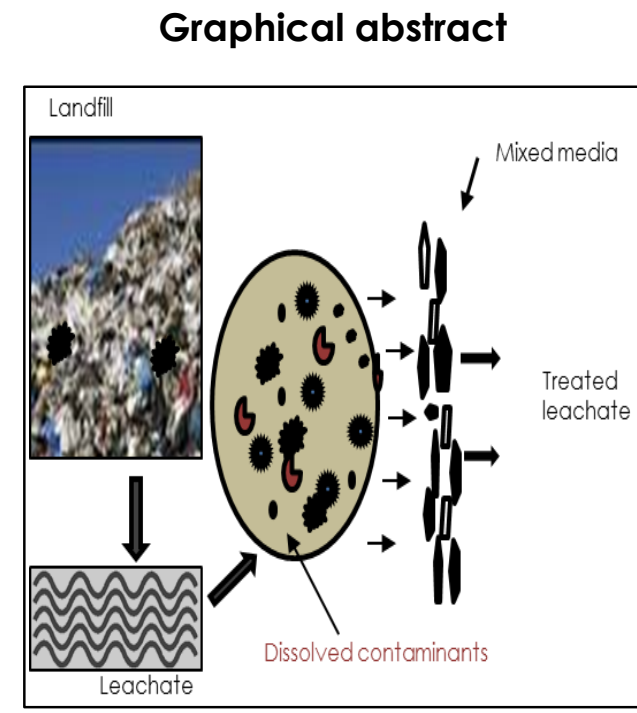

\begin{abstract}
Abstrak
Tapak pelupusan menjana larut resapan yang mengandungi kepekatan bahan pencemar yang tinggi dan berbahaya kepada kesihatan manusia dan ekosistem. Dalam kajian ini, campuran butiran yang terdiri daripada feldspar dan kulit kerang dikaji bagi pengurangan COD dan ammonia dari larut resapan di tapak pelupusan. Kesemua media penjerap disaring kepada saiz partikel di antara 2.00 dan $3.35 \mathrm{~mm}$. Hasil kajian menunjukkan bahawa campuran nisbah optimum feldspar dan kulit kerang adalah 20:20, kelajuan goncangan $150 \mathrm{rpm}, \mathrm{pH}$ 6, masa goncangan 120 min dan dosej sebanyak 30 g. Daripada analisis isoterma penjerapan mendedahkan isoterma Langmuir adalah lebih sepadan dengan data ujikaji berbanding isoterma Freundlich. Media penjerap yang dihasilkan memberi keputusan yang memberangsangkan dan berpotensi digunakan sebagai penjerap yang baik dan mampan.

Kata kunci: Kulit kerang, feldspar, COD, ammonia, larut resapan

(C) 2018 Penerbit UTM Press. All rights reserved
\end{abstract}




\subsection{INTRODUCTION}

Malaysia has an increasing problem of solid waste disposal, in which a large number of land disposal sites do not have sufficient or comprehensive facilities to adequately handle the ever-increasing waste generation and consequent leachate formation. Paradoxically, the main hazard to the environment from landfills that receive solid waste originates as a liquid. Diverse leachates are produced from the organic dissolution and densification of wet refuse, but the majority is produced by infiltration from precipitation, evaporation, surface runoff, and storage capacity. Infiltration primarily occurs during the landfill operational life, but the water may also enter in lesser amounts after closure due to leakage through the cap. This leachate (liquid) percolates in the landfill for several years, interacting with paints and spent petroleum products, pesticides, and a multitude of other items that contribute to making up the landfill. Aerobic and anaerobic degradation also occur under suitable conditions within the landfill. Leachate constitutes dissolved contaminants, volatile organic acids, toxic heavy elements, and high concentrations of chemical oxygen demand (COD) and ammonia [1-8]. When leachate containing high levels of dissolved contaminants is inadvertently discharged into the environment, it can contaminate the soil and water bodies, seriously threatening the environment and public health $(9,10)$. One of the sources of groundwater pollution is landfill leachate, which is also a major environmental concern at sanitary landfills that demands extensive controlling measures.

Leachate treatment imposes technical and economic challenges to water quality managers. Many landfill leachate treatments that apply the conventional approach involve high-technology processes. High-technology methods generate residues and are saddled with high initial and longterm operational expenditure as well as low applicability to many types of pollutants to achieve discharge standards [1 1, 12]. At present, an increasing amount of research involving the possible application of alternative adsorbents (10) to obtain appropriate leachate treatment or as a substitute approach to conventional media for the treatment of pollutants that exist in wastewater. Feldspar (F), which was successfully applied in the removal of heavy metals from industrial wastewater, is a promising adsorbent (10). Meanwhile, cockle shell (CS) is hydrophobic and primarily comprises $\mathrm{CaO}$ of nearly equal percentage ratio (96.28\%) as compared to that in limestone (97.67\%). Apart from being environmentally friendly, CS can be used for the removal of organic and inorganic pollutants in wastewater [13-15]. Furthermore, considerable research has investigated the use of conventional media involving a combination of activated carbon and zeolite for leachate remediation; however, attention on the application of alternative media as a substitute for conventional media in landfill leachate treatment is emerging [16-19]. The present article introduces the research results on leachate treatment using alternative biomedia. Batch experiments using combined loose media of CS and zeolite were conducted using one-factor-at-a-time optimization to determine the best ratio of adsorbents for COD and ammonia removal at ambient temperature, as well as the most effective conditions with respect to adsorbent dosage, $\mathrm{pH}$, agitation speed, and contact time on the adsorbent.

\subsection{METHODOLOGY}

Leachate sample was collected at simpang Renggam municipal landfill in Johor. Raw leachate was collected from the inlet of the detention pond using clean $20 \mathrm{~L}$ high-density polyethylene plastic containers. Then, leachate was characterized within $24 \mathrm{~h}$ according to the standard methods for the examination of water and wastewater [18-21]. Two different mixed media types (F and CS) were then used for the experiments. F and CS were cleaned according to Daud (14) and sieved to obtain particle sizes between 2.00 and $2.35 \mathrm{~mm}$. The determination of the optimum condition of shaking speed and time experiments was conducted in a series of $250 \mathrm{~mL}$ conical flasks containing $100 \mathrm{~mL}$ of raw leachate and some measured quantity by mass (equivalent to $40 \mathrm{~cm}^{3}$ ) of the mixed media by respectively varying the shaking speed and time. The influence of $\mathrm{pH}$ on COD and ammonia remediation was determined by varying the $\mathrm{pH}$ levels to $4,6,7,8$, and 9 . The $\mathrm{pH}$ variation was carried out with $97 \% \mathrm{H} 2 \mathrm{SO} 4$ and $1 \mathrm{M}$ $\mathrm{NaOH}$. Furthermore, optimum dosage was determined by varying the adsorbent dose from $4 \mathrm{~g}$ to $56 \mathrm{~g}$. The sequence of media mixing ratios for F:CS were 8:56, 16:48, 25:40, 33:32, 41:24, 50:16, and 58:8, which is based on mass (g) $(19,11)$. Finally, the optimum values of the combination of the two media were obtained by plotting mixing ratio against removal percentages of COD and ammonia.

\subsection{RESULTS AND DISCUSSION}

\subsection{Media Mix Ratio}

The percent removal of COD and ammonia nitrogen in the sample after mixing of feldspar with CS was analysed. The results show that the most favourable conditions occurred for COD and ammonia removal at 20:20 mix ratio which corresponds to $30 \%$ and $24 \%$ removal respectively for COD and ammonia by the media (Figure 1). The ratio 20:20 also represent about $50 \%$ replacement of the conventional media.

A one-tailed two-sample t-test was also used to ascertain whether the mix ratio of 20:20 removes more of the parameters compared to the generality of the 
mix ratios. The t-test results for $20: 20$ mix ratio was summarized in Table 1.

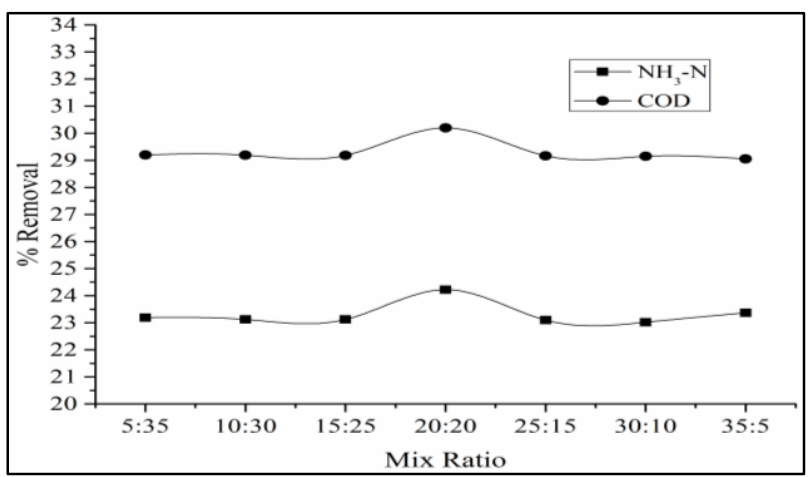

Figure 1 Mix ratio of adsorbents for $\mathrm{COD}$ and $\mathrm{NH}_{3}-\mathrm{N}$ removal

The results show that on average, the mix ratio 20:20 removed more of the COD and ammonia in comparison to the general mix ratios. The results also revealed that a significant difference exists for the $20: 20$ mix ratio data. It is also evident from data that statistically, mix ratio $20: 20$ is significant in removal as compared to the overall mix ratios.

Table 1 t-Test result

\begin{tabular}{lccccc}
\hline Parameter & N & mean & $\begin{array}{c}\text { All mix } \\
\text { ratio } \\
\text { mean }\end{array}$ & T-value & P-value \\
\hline NH3-N & 7 & 24.22 & 23.3045 & -5.798 & $<0.001$ \\
COD & 7 & 30.19 & 29.3037 & -5.953 & $<0.001$ \\
\hline
\end{tabular}

\subsection{Shaking Speed}

The optimum media mixing ratio of 20:20 was employed to determine the optimum shaking speed based on COD and ammonia removal. The percentage of $\mathrm{COD}$ and $\mathrm{NH}_{3}-\mathrm{N}$ decreased with the increase in agitation rate from 50 to $150 \mathrm{rpm}$. The result show that removal increased substantially from 50 up to 150 there after it decreased (Figure 2). The optimum shaking speed adopted for further experiment was $150 \mathrm{rpm}$. This shaking speed corresponds to COD and $\mathrm{NH} 3-\mathrm{N}$ removal rates of $40 \%$ and $30 \%$ respectively.

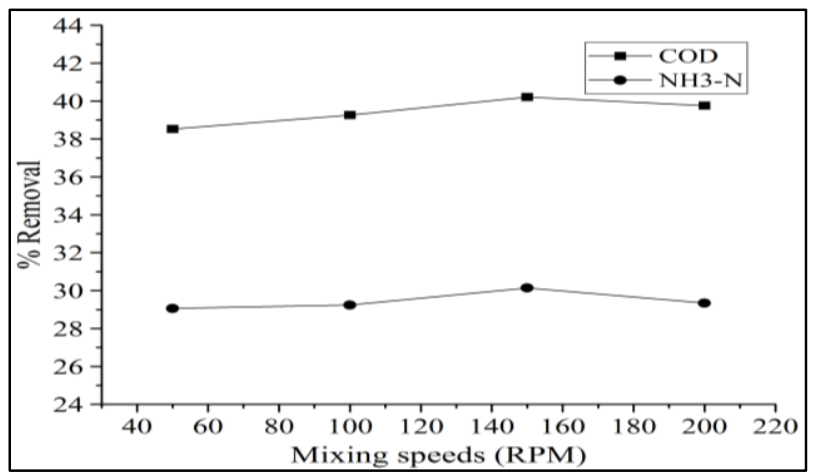

Figure 2 Mixing speeds of media for $\mathrm{COD}$ and $\mathrm{NH}_{3}-\mathrm{N}$ removal

\section{$3.3 \mathrm{pH}$}

$\mathrm{pH}$ is important for the determination of optimum parameters (18). The influence of $\mathrm{pH}$ on the removal of COD and ammonia was investigated by varying the $\mathrm{pH}$ of the solution between 2 and 9 .

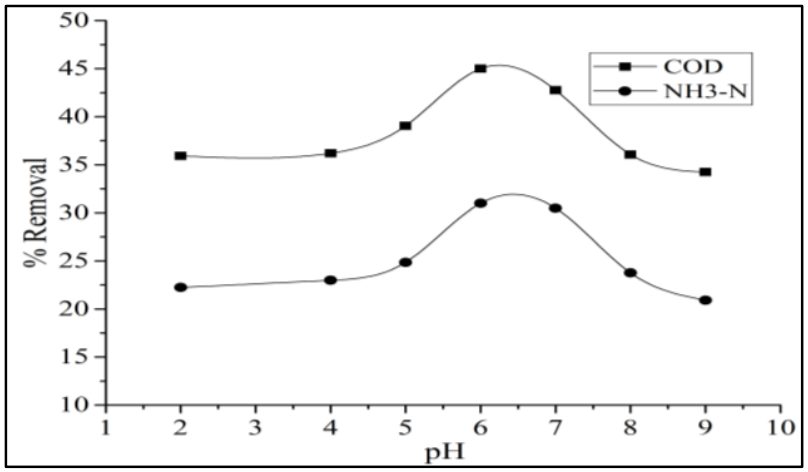

Figure 3 Optimum $\mathrm{pH}$ for $\mathrm{COD}$ and $\mathrm{NH}_{3}-\mathrm{N}$ removal

The results revealed that the removal rate was enhanced with the increase in $\mathrm{pH}$ until the $\mathrm{pH}$ reached 6 , and then steadily decreased until the $\mathrm{pH}$ reached 9. An optimum removal rate of $45 \%$ and $31 \%$ for COD and ammonia was achieved at $\mathrm{pH} 69$ Figure 3).

\subsection{Contact Time}

The concentration of adsorbate species in the bulk fluid and the interaction time between the adsorbent and adsorbate play dominant roles in minimizing pollutants from effluent water. The shaking time for COD and ammonia nitrogen removal by the adsorbent illustrated that the removal of COD was increasing with the increment in time (see figure 4) and attained equilibrium in about $120 \mathrm{~min}$. Similarly, ammonia nitrogen removal was found to be $120 \mathrm{~min}$. The shaking time of 120 min was adopted, for COD and ammonia nitrogen removal which corresponds to $55 \%$ and $39 \%$ respectively.

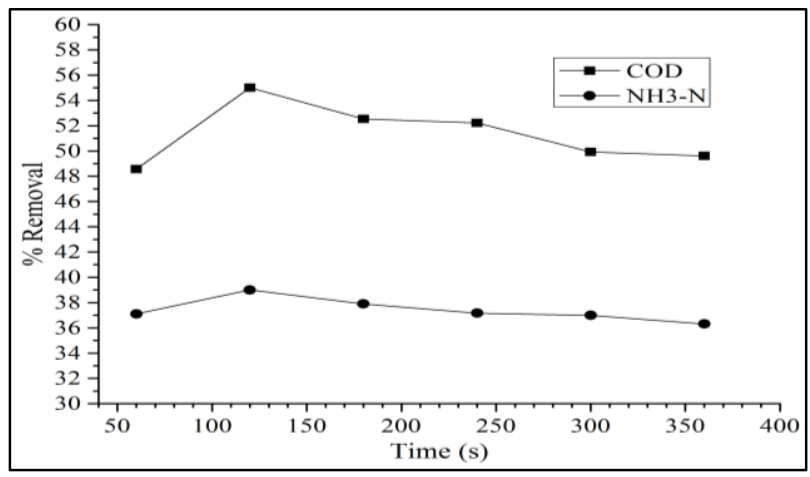

Figure 4 Optimum shaking time for $\mathrm{COD}$ and $\mathrm{NH}_{3}-\mathrm{N}$ removal 


\subsection{Dosage of Media}

Inadequate dosage or excess dosage of media may lead to an inadequate capacity in parameter removal.

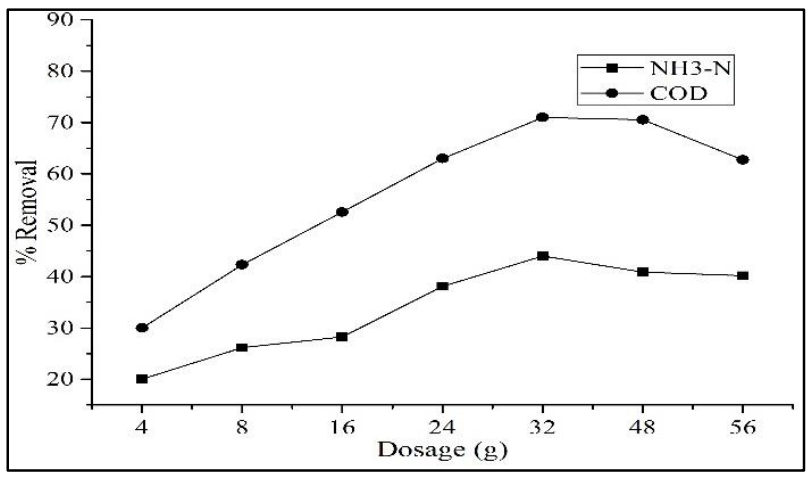

Figure 5 Optimum dosage for $\mathrm{COD}$ and $\mathrm{NH}_{3}-\mathrm{N}$ removal

The effect of adsorbent concentration on adsorption of COD and ammonia was determined by varying the dosage in the range of 4-56 $\mathrm{g}$ using predetermined optimum conditions (mixed ratio of 20:20, shaking speed of $150 \mathrm{rpm}, \mathrm{pH}$ level of 6 , and shaking time of $120 \mathrm{~min}$ ).

From the results, the percentage removal of the adsorbate increased with the increase in the adsorbent dose until $32 \mathrm{~g}$ dosage was reached (Figure 5). At this dosage, the COD and ammonia nitrogen removal rates was $71 \%$ and $44 \%$ respectively. This behaviour can be credited to an increase in the amount of available sorption sites from the onset until the optimum mass is reached, any further increase in the adsorbent dose results in aggregation, which can decrease the chances of occurrence for available sorption sites for the molecules.

\subsection{Adsorption Isotherms}

The determination of the adsorption isotherms is important for the optimization of sorption experiments. The two well-known adsorption isotherms (Langmuir and Freundlich) have been used for this study. The Langmuir isotherm analyzes the formation of a monolayer adsorbate onto the adsorbent surface. On the other hand, the Freundlich isotherm model explains heterogeneous surface adsorption, in which the surface concentration of the adsorbate on the adsorbent increases with the elevation in the initial concentration of the solution. The correlation coefficients R2 demonstrate or differentiate suitability of each equation.
Table 2 Coefficients of Langmuir isotherm models for COD and $\mathrm{NH} 3-\mathrm{N}$ uptake by the media

\begin{tabular}{llll}
\hline & \multicolumn{3}{c}{ Langmuir constant } \\
\cline { 2 - 4 } & \multicolumn{1}{c}{$\mathbf{q}_{\mathbf{m}}$} & $\mathbf{K}_{\boldsymbol{l}}$ & $\mathbf{R}^{\mathbf{2}}$ \\
\hline $\mathrm{COD}$ & 40.81 & 0.0959 & 0.8861 \\
$\mathrm{NH}_{3}-\mathrm{N}$ & -987.87 & 4.4343 & 0.7549 \\
\hline
\end{tabular}

Table 3 Coefficients of Freundlich isotherm models for COD and NH3-N uptake by the media

\begin{tabular}{llll}
\hline & \multicolumn{3}{l}{ Freundlich constant } \\
\cline { 2 - 4 } & $\boldsymbol{l o g} \boldsymbol{K}_{\boldsymbol{f}}$ & $\mathbf{1} / \boldsymbol{n}$ & $\mathbf{R}^{\mathbf{2}}$ \\
\hline $\mathrm{COD}$ & 0.3784 & 0.2788 & 0.7461 \\
$\mathrm{NH}_{3}-\mathrm{N}$ & -1.513 & 3.7189 & 0.8814 \\
\hline
\end{tabular}

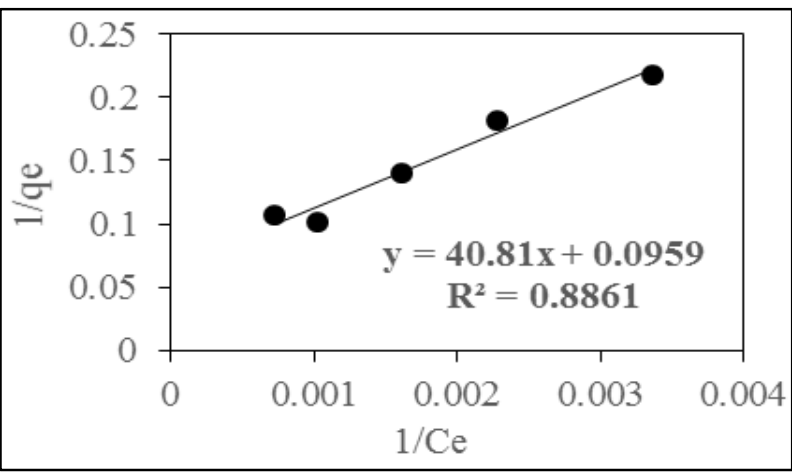

Figure 6 Langmuir Isotherm for COD adsorption

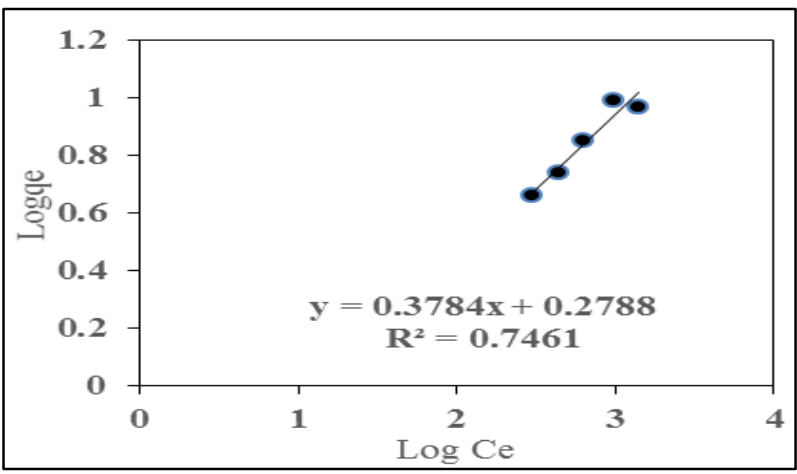

Figure 7 Freundlich Isotherm for COD adsorption

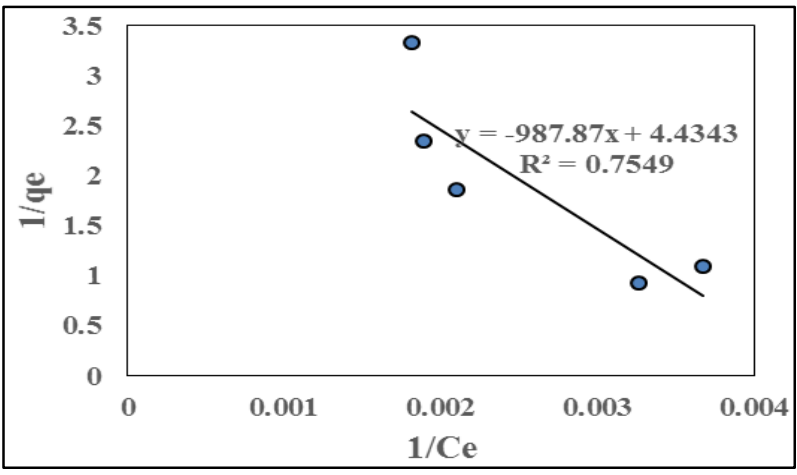

Figure 8 Langmuir Isotherm for $\mathrm{NH}_{3}-\mathrm{N}$ adsorption 


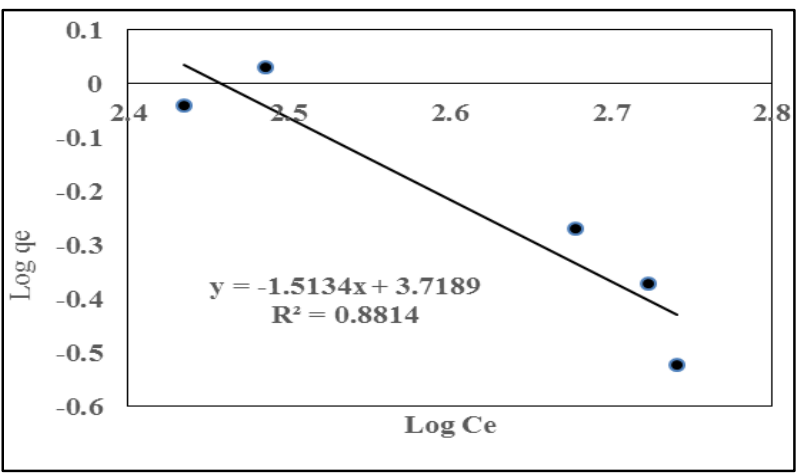

Figure 9 Freundlich Isotherm for $\mathrm{NH}_{3}-\mathrm{N}$ adsorption

The correlation value obtained for the Langmuir and Freundlich equations for COD shows that the value of $R^{2}$ was higher in Langmuir than in Freundlich. Similarly, the R2 values for $\mathrm{NH} 3-\mathrm{N}$ were higher in Freundlich (see Table 2 and 3 ). This finding indicates that the Langmuir isotherm model is more suitable than Freundlich isotherm for evaluating the adsorption equilibrium required for COD, implying monolayer formation while Freundlich was favourable in ammonia uptake by the media, which also indicates heterogeneous surface adsorption. The fitting of the Langmuir isotherm for COD by similar adsorbents was also reported in another study by Siti et al. (22) and Daud (23).

\subsection{CONCLUSION}

The effectiveness of the mixture of CS and F as adsorbents was determined for the removal of ammoniacal nitrogen and COD from a landfill leachate. The pertinent parameters of mixing ratio, shaking speed, shaking time, $\mathrm{pH}$, and adsorbent dose that define the optimum conditions were determined as follows: mixing ratio of 20:20, shaking speed of 150 rpm, pH level of 6, shaking time of $120 \mathrm{~min}$, and dosage of $30 \mathrm{~g}$. The adsorption isotherm analysis reveals that both Langmuir and freundlich isotherms fit the experimental data. The media can be used as an economical adsorbent for stabilized landfill effluent treatment. Furthermore, investigation is being performed to ascertain other aspects like desorption as well as disposal of used up adsorbents that may influence the research area.

\section{Acknowledgement}

The authors acknowledge the research grant (FRGS Vot. No. 1571) provided by the Ministry of Higher Education, Malaysia.

\section{References}

[1] Mohajerani, Abbas, Aeslina Abdul Kadir, and Luke Larobina. 2016. A Practical Proposal for Solving the World's Cigarette Butt Problem: Recycling in Fired Clay Bricks. Waste Management. 52: 228-244.

[2] Othman, Norzila, Y. S. Kueh, F. H. Azizul-Rahman, and Rafidah Hamdan. 2014. Watermelon Rind: A Potential Adsorbent for Zinc Removal. Applied Mechanics and Materials. 680: 146-149.

[3] Kamaruddin, Mohamad Anuar, Mohd Suffian Yusoff, Hamidi Abdul Aziz, and Nur Khairiyah Basri. 2013. Removal of COD, Ammoniacal Nitrogen and Colour from Stabilized Landfill Leachate by Anaerobic Organism. Applied Water Science. 3(2): 359-366.

[4] Daud, Z., Hatta, M. Z. M., Kassim, A. S. M., Awang, H., \& Aripin, A. M. 2014. Exploring of Agro Waste (Pineapple Leaf, Corn Stalk, and Napier Grass) by Chemical Composition and Morphological Study. BioResources. 9(1): 872-880. http://doi.org/10.15376/biores.9.1.872-880.

[5] Adeleke, A. R. O., Abdul Latiff, A. A., Daud, Z., Ridzuan, B. and Mat Daud, N. F. 2016. Remediation of Raw Wastewater of Palm Oil Mill Using Activated Cow Bone Powder through Batch Adsorption. Key Engineering Materials. 705: 380-384. http://doi.org/10.4028/www.scientific.net/KEM.705.380.

[6] Adeleke A. O., Ab Aziz Ab Laatiff, A. A. Al-Gheethi., and Zawawi D. 2017. Optimization of Operating Parameters of Novel Composite Adsorbent for Organic Pollutant Removal from POME using Response Surface Methodology. Chemosphere.174: 232-242. http://doi.org/10.1016.

[7] Habeeb, S. A., Latiff, A. A. A., Daud, Z., and Ahmad, Z. 2011. The Start-up of Hybrid, Anaerobic Up-fow Sludge Blanket (HUASB) Under a Range of Mesophiclic and Thermophilic Temperatures. Environment Asia. 4(2): http://doi.org/10.14456/ea.2011.19.

[8] Rahaman, A. A., Latif, A. A. A., Daud, Z., Ridzuan, M., and Jagaba, A. 2016. Preparation and Characterization of Activated Cow Bone Powder for the Adsorption of Cadmium from Palm Oil Mill Effluent. Materials Science and Engineering. 136(July): 1-6. http://doi.org/10.1088/1757$899 \times / 136 / 1 / 012045$.

[9] Mokhtar, N., Aziz, E. A., Aris, A., Ishak, W. F. W., \& Ali, N. S. M. (2017). Biosorption of Azo-dye Using Marine Macro-alga of Euchema Spinosum. Journal of Environmental Chemical Engineering. 5(6): 5721-5731.

[10] Rddy, A. V. B., Yusop, Z., Jaafar, J., Jamil, N. H., Majid, Z. A., \& Aris, A. B. 2018. Development and Validation of Capillary Electrophoresis Method for Simultaneous Determination of Six Pharmaceuticals in Different Food Samples Combining On-line and Off-line Sample Enrichment Techniques. Food Analytical Methods. 11 (2): 533-545.

[11] Rosli, M. A., Daud, Z., Awang, H., Zainorabidin, A., \& Halim, A. A. 2017. The Effectiveness of Peat-AC Composite Adsorbent in Removing SS, Colour and Fe from Landfill Leachate. International Journal of Integrated Engineering. 9(3).

[12] Ramya, R., P. Sankar, S. Anbalagan, and P. N. Sudha (2011). Adsorption of $\mathrm{CU}$ (II) and Ni (II) lons from Metal Solution Using Crosslinked Chitosan-G-Acrylonitrile Copolymer. International Journal of Environmental Sciences. 1(6): 13231338.

[13] Abubakar, M. H., Belel, Z. A., \& Abba, H. A. 2017. Evaluation of the Groundwater Quality in Pariya. International Journal of Integrated Engineering. 8(3).

[14] Daud, Z., Abubakar, M. H., Kadir, A. A., Aziz, A., Latiff, A., Halim, A. A., \& Marto, A. 2017. Adsorption Studies of Leachate on Cockle Shells. International Journal of GEOMATE. 12(29): 46-52.

[15] Daud, Z., Hijab Abubakar, M., Abdul Kadir, A., Abdul Latiff, A., Awang, H., Abdul Halim, A., \& Marto, A. 2016. Optimization of Leachate Treatment with Granular Biomedia: Feldspar and Zeolite. Indian Journal of Science 
and Technology. 9(37): 11-15. http://doi.org/10.17485/ijst/2016/v9i37/91845.

[16] Halim, Azhar Abdul, Kee Ke Han, and Marlia Mohd Hanafiah. 2015. Removal of Methylene Blue from Dye Wastewater Using River Sand by Adsorption. Nature Environment and Pollution Technology. 14(1): 89.

[17] Latiff, A. A. A., Adeleke Abdul Rahman, O., Daud, Z., Ridzuan, M. B., \& Mat Daud, N. F. 2016. Batch Adsorption of Manganese from Palm Oil Mill Effluent Onto Activated Cow Bone Powder. ARPN Journal of Engineering and Applied Sciences. 11(4): 2627-2631. Retrieved from https://www.scopus.com/inward/record.uri?eid=2-s2.084960362078\&partner ID $=40 \& \mathrm{md} 5=\mathrm{d} 8449 \mathrm{f} 9$ eeb93a $194 \mathrm{ccfe}$ $5 f \mathrm{f} 4 \mathrm{~b} 5496 \mathrm{f} 80$.

[18] Standard Methods for the Examination of Water and Wastewater. 2012. Washington, DC: American Public Health Association (APHA).

[19] Halim, A. A., Aziz, H. A., Johari, M. A. M., \& Ariffin, K. S. 2010. Comparison study of Ammonia and COD Adsorption on Zeolite, Activated Carbon and Composite Materials in Landfill Leachate Treatment. Desalination. 262(1): 31-35.
[20] Daud, Z., Nasir, N., Aziz Abdul Latiff, A., Ridzuan, M. B., \& Awang, H. 2016. Treatment of Biodiesel Wastewater by Coagulation-flocculation Process Using Polyaluminium Chloride (PAC) and Polyelectrolyte Anionic. ARPN Journal of Engineering and Applied Sciences. 11 (20): 1 1855-11859.

[21] Nasir, Z., and D. Z. 2014. Performance of Aluminium Sulphate and Polyaluminium Choloride In Biodiesel Wastewater. Journal of Mechanical Engineering and Sciences (JMES). 7(December): $1189-1195$. http://doi.org/http://dx.doi.org/10.15282/jmes.7.2014.18.0 116.

[22] Siti Nur Fatihah Moideen, Fadhil, M., Rezania, S., Ponraj, M. Rahman, A. A., Wen, L., Zulhilmi, I., Shazwin, M., Yu-you, L., Komori, D. 2017. Dual Phase Role of Composite Adsorbents Made from Cockleshell and Natural Zeolite In Treating River Water. Journal of King Saud University - Science. 6-11. http://doi.org/10.1016/j.jksus.2017.06.001.

[23] Daud, Z., Abubakar, M. H., Kadir, A. A., Latiff, A. A. A., Awang, H., Halim, A. A., \& Marto, A. 2017. Batch Study on Cod and Ammonia Nitrogen Removal Using Granular Activated Carbon and Cockle Shells. IJE TRANSACTIONS A: Basics. 30: 937-944. 